\author{
$\$$ \\ Territorio, poblamiento y arquitectura. \\ México en las Relaciones geográficas \\ de Felipe II \\ Rafael López Guzmán \\ Granada, Universidad de Granada/Atrio Editorial/ \\ Colegio Oficial de Aparejadores y Arquitectos Técnicos/ \\ Fundación El Legado Andalusí, 2007 \\ por \\ ELISA GARCÍA BARRAGÁN
}

Ésta es sin duda una publicación esencial para la historiografía del siglo xvI, pues se integra con escritos relativos a la geografía, la historia, la arquitectura y el arte, entre otros aspectos. Su autor, Rafael López Guzmán, plantea sus objetivos y metodología, y de manera sucinta explica lo que va a abordar en el análisis mediante el cual dará vida al mundo de la primera centuria del Virreinato. En la misma introducción consigna la génesis del trabajo llevado a cabo tanto en Espańa como en México, cita a los maestros y amigos que lo han acompańado significativamente en su constante exploración de tan vastos territorios y, sobre todo, da fe de una devoción hacia este país y su cultura.

Laboriosidad, inteligencia y sensibilidad han dado pie a esta edición fundamental. Por ello el esfuerzo del investigador, a partir de la revisión de las Relaciones geográficas de Felipe II, cuaja con éxito en el presente libro. Convencido de que esas descripciones cumplieron su objetivo, las sigue conforme a cierto orden: la demografía, el urbanismo y la historia de las instituciones, al lado de una acuciosa observación de las obras monumentales objeto de estudio.

Incuestionablemente, el punto de partida es su aproximación a aquel mandato del monarca, emitido con fines de entender los territorios de la Nueva Espańa — y reforzado mediante diversos acicates administrativosy así estar al tanto de la realidad de América. López Guzmán lo advierte todo y revela los puntos centrales contenidos en dichas Relaciones, lo cual podría parecer fácil, pero al inspeccionar la copiosa información se percata de que resulta prioritaria una aproximación puntual y una exploración documentada. Así, recorre varios repositorios de México, entre ellos el Archivo General de la Nación, las bibliotecas universitarias, la Nacional de México, las de los Institutos de Investigaciones Estéticas, Geográficas e Históricas, y, en 


\section{DOI: http://dx.doi.org/10.22201/iie.18703062e.2009.95.2298}

\section{84}

España, el Archivo General de Indias de Sevilla, la Biblioteca de la Real Academia de Historia y la Biblioteca Nacional de Madrid, además de otros.

A lo anterior se une la amplísima bibliografía que complementa el examen, y en ella la insoslayable referencia a quienes primero se ocuparon de esos escritos. Son muchos los nombres de autores con los que concuerda y siente empatía, pero igualmente abundantes son los de quienes sostienen ideas divergentes de las suyas, aunque no deja de lado la autoridad de estos últimos, pues le permiten una mayor objetividad en sus consideraciones. Especial atención le mereció la obra de René Acuña (de 1982) titulada Relaciones geográficas del siglo XVI, pues la atinada mención de sus muchos volúmenes se entreteje con las observaciones del propio doctor López Guzmán.

Esmerada es la referencia al amplio cuestionario enviado desde el Consejo de Indias, que interpreta la voluntad del monarca, aspira a encuestar a los habitantes del territorio novohispano y se dirige principalmente "a los virreyes y a las audiencias", como se advierte en la siguiente pregunta:

\footnotetext{
a los pueblos de españoles se les demanda la situación geográfica (orientación, distancias, comunicaciones), historia, población y reservas económicas; se pide también la "traza del pueblo". A los pueblos de indios, "historia local, desde la época prehispánica y etnografía (vestidos, alimentos, salud, medicina, ritos y costumbres)".
}

Lo pedido por Felipe II ya manifiesta la envergadura del quehacer que el doctor López Guzmán inició hace dos décadas, al acometer la ardua tarea de revisarlo todo y dar fe, mediante el trabajo de campo, de la exactitud de las res- puestas de entonces, que integraron un corpus contundente, perceptible in situ hoy día. El estudioso, consciente de las imágenes que dieron certitud a los resultados que acompañaron aquel cuestionario, las revisa e incorpora a su libro. Veraces y atractivas son esas ilustraciones, de las que, afirma, desafortunadamente no se conservan todas, pues sólo queda un total de 67 de ellas, aunque guardan afinidad con el retrato inscrito en algunos códices, es decir "los mensajes básicos van formulados por medio de pictogramas y complementados por glifos ideográficos”. Al respecto, López Guzmán subraya la calidad de estos testimonios:

El valor artístico de los pictogramas de tradición prehispánica[...]no es desdeñable, y hemos de cotejar que los motivos utilizados en estas representaciones coinciden en buena parte con los hallados en cerámicas y paramentos de edificios.

Respecto a quién o quiénes respondieron a lo demandado desde España, el historiador informa que, al lado de las autoridades novohispanas, fue numerosa la participación autóctona, y subraya que en ella concurrieron personajes de la nobleza junto a los trabajadores indígenas, traductores o artesanos, quienes aportaron su especial sensibilidad.

Con la edición aquí comentada, el autor cancela lagunas existentes en tan amplio campo, demostrando la idónea metodología con que le fue posible desvelar los aspectos que conformaban el día a día en aquellos recién fundados territorios.

Nada queda al azar: López Guzmán no olvida las distancias y en las tablas comparativas que inscribe indica las leguas y sus equivalencias en medidas entonces más en uso: "los 
pasos". Los pormenores de tales referencias y el carácter curioso de ellas imprimen amenidad al relato.

Casi a vuelo de pájaro, pues el prolijo texto no permite glosarlo más cabalmente, es posible comentar que la revisión paralela de los centros urbanos europeos y los de la Nueva España brinda al autor una perspectiva de grandes dimensiones y enorme riqueza que refleja la vida indígena, siempre dispuesta a integrarse en actos comunitarios; de ahí que quede explicada la grandilocuencia de los lugares de reunión: las plazas. Respecto al panorama histórico de las divisiones territoriales del siglo Xvı, añade lo mucho que influyó en tal amplitud lo que se ha llamado los "espacios de la Evangelización”, que, como bien sintetiza el estudioso, fusionan la "tradición prehispánica con la organización del Estado absoluto y las propuestas religiosas".

Al hablar de capítulos, es insoslayable mencionar la adecuada estructuración de este libro, que se desarrolla en seis partes. En la segunda de ellas, se insiste en la necesidad de comparar las ilustraciones con que acompañaban su información los encuestados. Acerca de los artificios de tan variados documentos visuales, se señala: "los Tlacuilos como guardianes de la historia interpretaban el mundo más en términos humanos que geográficos”. López Guzmán comenta a su vez que, "sin variar los elementos simbólicos, la calidad del dibujo, el color, el sombreado y el uso de la perspectiva, otorgan valores estéticos a las representaciones que permiten juzgar técnicamente al ejecutante". En efecto, aunque la calidad plástica no es homogénea, las presencias en estas descripciones pictóricas responden a lo solicitado por el monarca, en cuanto a construcciones, a límites, sin dejar de lado paisajes, vegetaciones, fauna de las diversas regiones $\mathrm{y}$, por supuesto, la presencia del hombre; en muchos casos, el artista se exigía un claro naturalismo, pues lo movía el deseo de alcanzar veracidad en lo capturado. Por ello, estoy segura de que incluir en el libro las láminas a las que tuvo acceso el investigador constituye un gran acierto, ya que el lector puede efectuar así un deleitoso recorrido por aquellos pretéritos sitios y conocer su vida cotidiana, y las atractivas imágenes poseen además el carácter de documentos históricos invaluables.

En el extenso texto acerca de la arquitectura, la referencia de la diversidad de materiales constructivos hace más notoria la participación conjunta de los españoles con los trabajadores naturales. López Guzmán lo ejemplifica con lo informado acerca de la región de Michoacán, pues en la Relación a propósito de ella se lee:

eran destacables los trabajos de carpintería, tanto en muebles como en arquitectura, lo cual era [...] posible por haber aquí muy buenos y pulidos carpinteros indios y muy primos; $y$ todo lo dicho se da a pintar a pintores que hay en estos pueblos los más pulidos y curiosos [...] Asimismo estos pintores darán cualquier imagen muy bien.

El autor no deja de mencionar los rollos y picotas, elementos de impartición de justicia, así como los planos y la descripción de las grandes construcciones: conventos, iglesias y hospitales, que permiten — y así lo afirmadatar algunos de esos edificios; sin embargo, el propio López Guzmán advierte:

Considero que una de las aportaciones importantes de este trabajo radica en el análisis de la vivienda popular. Los estudios que se han realizado sobre la misma se basan, de forma 


\section{DOI: http://dx.doi.org/10.22201/iie.18703062e.2009.95.2298}

\section{86}

\section{B ROS}

genérica, en trabajos de campo y entrevistas de maestros y gentes de los ámbitos rurales tradicionales [...] Estos datos, insisto, abren un campo de investigación de enorme interés que se tiene que completar con metodologías específicas ya utilizadas en este tipo de análisis.

Tampoco olvida López Guzmán referir testimonios artísticos: las pinturas elaboradas por los indios en los muros de las casas habitación, y no sólo en conventos. Y además insiste en el carácter prioritario de la "cotejación visual" del observador directo, que permite definir las características de un número importante de poblaciones del Virreinato. Se puede decir, con razón, que este minucioso repaso representa para el lector una especie de fantástico viaje que le deja satisfacciones y despeja ciertas incógnitas. $\mathrm{Al}$ recorrer su contenido, le queda claro, como indica el autor, que no únicamente las iglesias de una sola nave, sino también los planos y la elevación de los grandes establecimientos mendicantes — que no pueden identificarse con otros del siglo XVI en Europa-, son peculiares expresiones mexicanas.

Las conclusiones del investigador son relativamente breves, pero muy ricas en ideas y en ellas aparecen replanteadas cuestiones fundamentales, como la aceptación de la nueva cultura por los indígenas. Una ruta honesta, ética, fruto de sus visitas a muchos de los lugares y ejemplos que describe, todo llevado a cabo con la libertad que proveen la sensibilidad y el conocimiento. El orden que el doctor López Guzmán dio a los asuntos, la clara presentación de ellos, las fotografías, muchas de su propia autoría, junto con los planos, mapas y espléndidas láminas que acompañan la obra Territorio, poblamiento y arquitectura de México en las Relaciones geográficas de Felipe II permiten afirmar con toda certeza que se trata de un libro imprescindible, de consulta obligada para estudiosos de cualquier aspecto de la historia, la geografía, la economía, la arquitectura y el arte del siglo Xvi, que se presenta además en una atractiva y bien cuidada edición.

\author{
ॐ \\ Modernidad arquitectónica en Sinaloa \\ Alejandro Ochoa Vega \\ México, Difocur, Sinaloa/Ayuntamiento de Culiacán/ \\ UAS-Facultad de Arquitectura y UAM-X, 2004 \\ por \\ JORGE ALBERTO MANRIQUE
}

Sobre la arquitectura moderna en la ciudad de México hay una bibliografía muy grande, que crece constantemente desde los años cincuenta del siglo xx. No ocurre lo mismo en el resto del país. En Monterrey, en Guadalajara, en Puebla y en otras ciudades ya han aparecido libros muy valiosos que se ocupan de los centros urbanos, así como de los aspectos generales de la arquitectura moderna. Pero en revistas y publicaciones escasean estudios que registren la actividad edilicia en el mapa completo de México. El libro Modernidad arquitectónica en Sinaloa, de Alejandro Ochoa Vega, viene a cumplir esa tarea, y lo hace con eficacia.

En I98I, Ochoa empezó a trabajar como joven profesor en la Universidad Autónoma de Sinaloa, en Culiacán. Se interesó en la arquitectura de la ciudad, inició sus investigaciones sobre este fenómeno y reunió información adecuada para cumplir su objetivo. Desde 1989 